\title{
INDFØDTE FOLK I VERDEN OG I ANTROPOLOGIEN
}

\author{
Introduktion
}

Dette nummer af Tidsskriftet Antropologi er blevet til på baggrund af mundtlige indlæg på en workshop med titlen Indfødte folk i den globaliserede verden. Den blev afholdt på Nationalmuseet i efteråret 1994 i et samarbejde mellem Institut for Antropologi, Københavns Universitet, Etnografisk Samling og IWGIA: Den internationale arbejdsgruppe for indfødte Folk. Nogle af indlæggene er blevet omarbejdet til artikler, andre har bibeholdt deres karakter af mundtlige fremstillinger.

En del af idégrundlaget for workshoppen var at indfødte folk kan betragtes som en slags antropologiens klassiske objekt, samtidig med at mainstream antropologien i de senere år har bevæget sig længere og længere bort fra den traditionelle etnografi, der så „objektet“" som en isoleret størrelse der måtte forstås som en selvberoende enhed. I begyndelsen af dette århundrede, på Franz Boas’ tid, var idealet at udforske de enkelte kulturer indefra og derefter sammenholde kulturerne i et komparativt perspektiv. Det var indianere man studerede, eller eskimoer eller stammefolk, og termen ,indfødt“ tilhørte kolonialismens vokabular snarere end antropologiens. Længere fremme i århundredet blev det, med antropologiens sociologiske, økonomiske og politiske drejning, etniske grupper, bønder og arbejdere der blev de kategorier faget arbejdede med, og man så dem $i$ et klasseperspektiv, ud fra deres indbyrdes relationer eller i forhold til storsamfundet og staterne. Det blev social forandring, integrations- og assimilationsdynamik og kulturelt forsvar på den ene side, og modernisering på den anden, der stod $i$ centrum af den antropologiske opmærksomhed.

I dag er ,,indfødt“ hovedsagelig en politisk term, således som det da også blev understreget i flere af indlæggene på workshoppen. Kategorien indfødte er i moderne forstand ikke en analytisk kategori, men en selv-definerende betegnelse der bruges i et politiskstrategisk spil om menneskerettigheder og ret til egen kultur. Det skal ikke forstås sådan at der er tale om en indholdsløs kategori, men det er tydeligt at dens indholdsbestemmelse er under stadig forhandling, en forhandling der i sig selv en del af hele den proces afkoloniseringsproces, globaliseringsproces eller politiseringsproces - som indfødte folks mobiliseringsbevægelse er et udtryk for. Indfødte folk selv er blevet aktører på den globale politiske scene, en scene der i det hele taget har fået mange flere medvirkende end i de mere overskuelige gamle dage da verden var nemmere at dele op i os og dem, 
hvad enten det nu var natives og kolonisatorer, arbejdere og kapitalister eller etniske minoriteter og stater.

Hensigten med workshoppen var at se på ,objektet,“ indfødte folk, både i et faghistorisk perspektiv og i et aktuelt teoretisk antropologisk perspektiv. De nutidige tendenser i antropologisk teoridannelse understreger at kulturer ikke er isolerede størrelser; man ser kulturbegrebet i et dynamisk og interaktionelt perspektiv og betjener sig af begreber som kulturel kompleksitet, de-territorialisering, hybride kulturformer, multikulturalitet, kulturblanding, globalisering, kreolisering osv. Man ønskede at åbne op for en diskussion af hvordan disse teoretiske begreber forholder sig til størrelsen indfødte folk, og hvorvidt og på hvilken måde de er i stand til at håndtere de „objekter“ som nu har gjort deres tilbagekomst som selv-definerende agenter på den verdenspolitiske scene. Et andet åbent spørgsmål var om de indfødtes indtræden på scenen, med deres selvopfattelse som kulturelle væsener med en binding til land og territorier kunne risikere at være medvirkende til at forstærke nogle forladte og i dag særdeles politisk ukorrekte opfattelser af territorialitet, substanskultur og - det virkeligt grimme ord i vore dage - „essentialisme.“

Endnu et motiv til at tage emnet op var et ønske om at se på antropologien i et anvendelsesperspektiv ud fra den kendsgerning at flere og flere udviklings- og hjælpeorganisationer rundt omkring i Danmark og verden arbejder med indfødte folk. Eller med oprindelige folk, urbefolkninger eller Fjerde Verdens folk. ${ }^{1}$ „Indfødte“ og ,oprindelige“ er nogenlunde lige gode eller lige dårlige betegnelser, med hver deres anakronistiske konnotationer til henholdsvis dem der venter på civilisationen, eller til det at nogle mennesker skulle være mere autentiske end andre. Urbefolkninger bruges i de øvrige skandinaviske lande som en veletableret term, men har heller ikke helt heldige konnotationer, og Fjerde Verdensfolk er en betegnelse der var glimrende dengang der fandtes en nogenlunde afgrænselig Første, Anden og Tredie verden, men som er mindre indlysende i dag hvor i hvert fald den Første og Anden er forsvundet og det stadig bliver vanskeligere at afgrænse den Tredie verden såvel i geografisk som i økonomisk og politisk forstand.

De forskellige danske betegnelser dækkes imidlertid alle af det engelske indigenous peoples som har en klar betydning i moderne international politisk sprogbrug og i det internationale menneskerettighedsarbejde.

Dette nummers titel Indfødte spiller naturligvis på de gængse indianerfilmstereotyper og kolonitidens billede af natives. Samtidig skulle den imidlertid gerne medvirke til på dansk at etablere betegnelsen i den moderne betydning af ordet indigenous, selv om det i den officielle danske sprogbrug hyppigere erstattes af termen oprindelig.

Men hvilke verdensborgere er det så der her i slutningen af det 20. århundrede kalder sig indfødte?

Der anslås at være 300-350 millioner mennesker på jorden der falder ind under karakteristikken. De definerer sig selv som sådanne, de ses af sig selv og andre som besiddere af en særlig kultur og socio-økonomisk livsmåde der står i modsætning til majoritetssamfundet, og de lever på et geografisk sted hvor de har været forud for senere indtrængende folk og kulturer. De steder i verden hvor en kolonisering har fundet sted på et bestemt historisk tidspunkt, som i Nord- og Sydamerika, er det forholdsvis let at afgrænse hvem der er indfødte folk. Andre steder er et kriterium der går på ,hvem der var der først“" mere problematisk eller direkte ubrugeligt. Maasaierne i Kenya var f.eks. ikke de første folk i de områder hvor de nu er kvægnomader, men de er alligevel indfødte. I Jens Dahls artikel 
kan man læse en nærmere udredning af termen og hvordan denne kategori er blevet til i et historisk perspektiv.

Ud fra en sådan afgrænsning af kategorien talte flere af workshoppens deltagere således om de bevægelser der sker på tre områder, nemlig i verden som sådan, i de indfødtes verden og i antropologiens verden.

\section{Det globale landskab}

Hvad ,verden som sådan“ angår, er et af de afgørende forhold, når den skal ses som konteksten for indfødte folks rettighedskamp, at der er kommet langt flere aktører på scenen end dengang da der først og fremmest var tale om et forhold mellem let identificérbare undertrykkere i form af kolonisatorer eller en stat og de undertrykte indfødte folk. Stater og folk defineres på nye måder. Nationalstaten er blevet blot én af en lang række transnationale aktører. Der er ngo'erne, de ikke-statslige organisationer, af hvilke mange er startet som græsrodsbevægelser og en del har vokset sig store og professionelle, internationale og magtfulde $\mathrm{i}$ en grad så de repræsenterer et markant element $\mathrm{i}$ dét internationale landskab indfødte folk bevæger sig i. Der er multinationale firmaer, der er overstatslige føderationer og institutioner. Sommetider er staten en allieret, sommetider ikke. Sommetider repræsenterer folk staten, sommetider ikke, sommetider føler de sig repræsenteret af den, til andre tider ikke. Billedet er - med et velkendt begreb inden for den aktuelle antropologi - blevet uhyre komplekst. Samtidig er der dog ingen tvivl om at den undertrykkende stat er i live og har det alt for godt. Der findes klar og utvetydig voldelig undertrykkelse af indfødte folk fra den indonesiske stats side i Østtimor, i Bangladesh og Brasilien for blot at nævne nogle. Og dog er det ikke målet for flertallet af verdens indfødte folk at løsrive sig fra staten endsige bidrage til staternes opløsning. De færreste "nationer" som nogle af dem kalder sig, eller grupper af indfødte folk, vil kunne eller er interesseret $\mathrm{i}$ at klare sig som selvstændige stater, og med enkelte undtagelser er målet snarere en eller anden form for hjemmestyre eller selvstyreordning, med udgangspunkt $i$ et frit forhandlingsforhold til den stat man er en del af. Et grundkrav for de indfødte folks repræsentanter, som forhandler i FN og andre internationale organer, er accepten af kollektive rettigheder. Man ønsker sikring af adgang til land og ressourcer, ret til undervisning på eget sprog, bevarelse af kulturel integritet og sikring mod diskrimination. I yderste forstand mod den konstant truende kulturelle og ligefrem fysiske udslettelse der er hverdagsbetingelserne for mange af verdens indfødte folk. Man ønsker sig sikring af de individuelle menneskerettigheder via en sikring af kollektive rettigheder til materielle såvel som kulturelle ressourcer. Såvel kravet om anerkendelse af kollektive rettigheder som kravet om selvbestemmelse inden for en stats grænser, frembyder en udfordring til den organisationsform og den rettighedstænkning med enkeltindividet som basisenhed der udgør grundlaget for den - vestlige - herskende verdensordning og ideologi.

Der er således, som Ulf Johansson Dahre hævder det, tale om en virkelig udfordring til nationalstaten i spørgsmålet om indfødte folk, og i dén forstand til hele den globale opbygning efter kolonialismen, konstrueret som den er på basis af nationalstaterne som grundenhed. Hermed udfordres også det internationale samfund. Man ser det blandt andet i Genève, som er scenen for hele FN's menneskerettighedspraksis. 
I Julian Burgers og Katja Kvaales artikler, der begge omhandler indfødte folk i FN, anskues FN henholdsvis indefra og udefra. Den første er FN-administratorens faktuelle redegørelse for de tiltag og institutioner der findes inden for systemet til varetagelse af indfødte folks interesser. Burgers artikel viser hvor langt indfødte folk er kommet inden for de seneste ti år og hvor mange forskellige organer, konventioner og erklæringer der direkte eller indirekte berører indfødte folks anliggender, uden at indfødte folks interesser dermed nødvendigvis er tilgodeset inden for systemet på den måde krav som selvbestemmelse og anerkendelse som folk indebærer. Artiklen viser også hvorledes de store politiske linier er afhængige af små administrative tiltag og langsommeligt forhandlingsarbejde om plads, penge og tid. Katja Kvaale beskriver på den anden side, i livlig impressionistisk form, og med et klart antropologisk perspektiv på grundlag af deltagerobservation, hvorledes indfødte folk gebærder sig på den internationale scenes bonede gulve og sætter deres etnicitet i spil som et led i bestræbelserne på at opnå de basale rettigheder.

Hanne Vebers artikel søger at sammenkæde mange af de komplicerede komponenter der indgår i hele det politiske, administrative og faglige spil. Hendes præmis er at diskursen om indfødte folk er etableret på grundlag af en bestemt opfattelse af deres kultur som bærende argumentation. Artiklen lægger op til en debat om sammenhængen i nogle samtidige bevægelser i det mentale - globale - landskab og i det konkrete verdenspolitiske landskab. Spørgsmålet er, om man som Veber gør det, kan sammenblande den populære opfattelse af oprindelige folk med det administrative og politiske arbejde blandt de ngo'er der er engagerede i dette arbejde, og som tredie element bevægelserne i den aktuelle (postmodernistiske) antropologiske teoridannelse. Artiklen rejser mange spørgsmål, men understreger samtidig nødvendigheden af at sammenholde de mange forskellige elementer der må indgå i en samlet forståelse af hele det globale spil.

En antropologisk debat om dette spil må forholde sig til hvordan kulturbegrebet inddrages heri. Det gælder det mere „,gammeldags“ kulturbegreb, og det gælder på hvilken måde de nyere dynamiske kulturopfattelser kan belyse hvad det er der foregår i form af politisk strategi, rettighedskamp og selvdefinition. Artiklerne i dette nummer nærmer sig dette spørgsmål fra forskellige vinkler. Der synes imidlertid at være nogenlunde enighed om at den internationale diskurs om indfødte folk er opstået i et politisk snarere end $i$ et kulturelt rum. Der er klart tale om en identitetsstrategi med politisk form. Når „kultur“ drages ind $\mathrm{i}$ argumentationen, må det også ses $\mathrm{i}$ lyset af den magtsituation inden for hvilken forhandlingerne foregår, og hvor der så klart er nogle der har større patent på definition af situationen end andre.

Flere af artiklerne behandler på forskellig måde forholdet mellem den retlige opfattelse af kategorier som folk og stat, og på den anden side den antropologiske analytiske opfattelse, i kraft af hvilken man ofte vil kunne afsløre hvordan rettigheder er knyttet til selve anerkendelsen af en kategori, eller hører til en kategori som netop bliver til i kraft af henvisning til fælles rettigheder. Dette er måske det forhold der, set fra et antropologisk synspunkt, kan få allermest konkret og praktisk betydning i det politiske arbejde med indfødte folk. 


\section{Bevisbyrden}

Line Læssøe Stephensen gav i sit mundtlige indlæg et klart eksempel på hvordan udviklingsmæssige og antropologisk teoretiske måder at anskue et indfødt folks problemer på - i dette tilfælde cocamaindianerne i det peruanske Amazonas - ikke nødvendigvis passer med dette folks selvopfattelse. I dette tilfælde kunne det vises hvordan selvopfattelsen hos det pågældende folk havde været bestemt af et ønske om at undgå diskrimination og marginalisering, hvorfor man havde omdefineret sig fra ,indianer" til en spansk betegnelse. Men cocamaindianerne har stadig en synlig indianskhed og deler et særligt forhold til jorden, dyrkningsmetoder, kollektive arbejdsmetoder og fest- og musiktraditioner med andre amazonfolk. Via det selvorganiseringprojekt der støttes med dansk udviklingshjælp, omdefinerede cocamasamfundet sig således fra en spansk pueblo til et indiansk samfund med de juridiske rettigheder det nu medfører.

Ulla Hasager giver i sin artikel lysende eksempler på striden om begreber som tradition og kultur der udfordres og sættes under diskussion i retsager omkring landrettigheder på Hawaii og i Australien. I den forbindelse er det værd at huske på - hvilket da også med jævne mellemrum bliver fremdraget af indfødte folks repræsentanter i FN-systemet når de udfordres med krav om præcise definitioner på hvem der hører ind under kategorien indfødte folk - at man i international retspraksis opererer med en hel del andre begreber der ikke har en fast og eksplicit definition, herunder så centrale størrelser som „folk“ og ,minoritet“. Hasagers eksempler berører desuden spørgsmålet om bevisbyrde i form af henvisning til oldgamle og statiske kulturer og traditioner og stiller retorisk spørgsmålet om man ikke hellere skulle tage udgangspunkt i nutidig praksis og kulturopfattelse. Frem for alt retter denne artikel linsen mod antropologernes rolle i hele dette spil om kultur og tradition og rettigheder.

Ønsker man fra en anden led at vide hvilke realiteter truslerne mod indfødte folks samfund indebærer, kan man læse Georg Henriksens beretning om fællesskabets opløsning og den individuelle og kollektive smerte der følger heraf, hos mushuau innu i Labrador. Her bliver sammenhængen mellem den strukturelle vold det indfødte samfund udsættes for, og den følelsesmæssige oplevelse af håbløshed og følgelig selvdestruktion smertelig klar.

Truslerne mod indfødte folks livsgrundlag kommer fra de omliggende samfund og fra de globale relationer de er indlejrede i. Men kontakten ud i verden er for det første ikke nødvendigvis noget nyt, for det andet er den ikke altid ødelæggende. Frank Sejersen viser, på baggrund af en historisk gennemgang, hvordan arktiske folk altid har været påvirkede af og selv påvirket relationerne ud $\mathrm{i}$ verden, og stik imod hvad der ligger $\mathrm{i}$ den gængse forestilling, har været involverede i et større felt af relationer og i vidt omfang styret dette på deres egne præmisser. I dag kommer truslerne mod dem også fra ,kulturpolitiet“, fra en placering af indfødte folks samfund og kulturer uden for en forestillet moderniserings- og udviklingsfære. Sejersen viser hvordan konsekvenserne af de moderne økopolitiske ideologier mærkes i form af antifangstorganisationers mistænkeliggørelse og miskreditering af indfødte folk, på baggrund af en kulturforståelse der indebærer at disse folk ikke er berettigede til at kalde sig indfødte når de ,udnytter“ naturen. Det sker ud fra en fejlagtig forestilling om ,indfødthed“" som den ubesmittede, paradisiske, vegetariske naturtilstand der udelukker enhver menneskelig form for indgriben i naturen i form af dyredrab eller snescootere i landskabet. 


\section{Autenticiteten og det refleksive}

Et spørgsmål der dukker op i mange artikler, er spørgsmålet om autenticitetens vilkår i den moderne verden. Autenticiteten som udfordret udefra, som når indfødte folk afkræves bevis om autenticiteten af den kultur de påkalder sig. Herunder hører også spørgsmålet om autenticiteten i den bevidste brug af etniske markører. Niels Fock taler i sit indlæg om det performative i det politiske. Samtidig introducerer han hvad han kalder det diætetiske kulturbegreb, forstået som alle de selvfølgelige og ikke ekspliciterede kulturelle regler der kun kan afsløres ved at de brydes. Man kan her hævde at begge dele er lige autentiske, men at konteksten for autenticiteten må forstås forskelligt. Et møde i Arbejdsgruppen for indfødte Befolkninger eller i Menneskerettighedskommissionen i Genève har mange ligheder med en performance. Der er de bevidst æstetiske markeringer fra de indfødte repræsentanter - maasaier, samer, chakmaer - i form af en etnisk dragt den ene dag og jakkesættet eller spadseredragten den næste. Hver især og tilsammen er de markeringer af både kulturel og politisk art, og markeringer der gør en forskel og ikke er uægte, selv om det kan have karakteren af at være „klædt ud“, at fremstille sig.

Flere af artiklerne giver anledning til en påmindelse om at den frygt for at essentialisere kultur som er en følge af den moderne antropologis af-essentialiseringen af kulturbegrebet, ikke bør komme til at bevirke at man afskærer sig fra mulighederne for at se på hvordan „kultur“, med det kulturbegreb antropologien selv har været med til at skabe, bringes ind i en politisk strategisk kamp. Der er ikke så meget tale om en advarsel mod essentialisering, heller ikke mod at overtage de kulturelle folkemodeller, men måske en advarsel mod berøringsangst over for sådanne folkemodeller, eller indfødte kulturopfattelser, som støder den moderne antropologiske bevidsthed. Når indfødte folk benytter et kulturbegreb antropologien har lagt bag sig, så betyder det noget. Ikke nødvendigvis det det siges at betyde, men noget andet, og dette andet bør i allerhøjeste grad have antropologiens opmærksomhed. Herunder hører naturligvis hvordan kultur bringes i spil i den politiske proces. Heri ligger der en høj grad af kompleksitet. I det hele taget viser indlæggene at kulturel og samfundsmæssig kompleksitet ikke kan henføres til en bestemt type samfund, såsom det højtindustrialiserede vestlige samfund, og da slet ikke befinder sig uden for det felt der omfatter indfødte folk. Kompleksitet er der også i måden hvorpå et indfødt folk i den moderne, globaliserede verden interagerer med staten og det omgivende samfund, og set i et globalt perspektiv, i de mange elementer der indgår i den internationale bevægelse indfødte folks synliggørelse på den verdenspolitiske scene er. Som Jens Dahl siger det, er også indfødte samfund i dag komplekse samfund. Der er mange steder opstået en elite som er den der fører forhandlingerne med staterne og det internationale samfund, og det er ikke nødvendigvis denne elite der er den mest repræsentative for lokalsamfundets kultur. Dette kan igen ses i relation til skismaerne i Ulla Hasagers tre beretninger fra det virkelige samliv mellem antropologer og indfødte, hvor der gennem retsager skal føres bevis for at en kulturel tradition ikke er tabt. Her som andre steder ses det tydeligt hvordan rettighedskampen bliver en udfordring til de forskellige indefra og udefra anskuede kulturopfattelser. Som Fock siger det, må politiske ledere ,eksplicitere noget kulturelt der egentlig kun eksisterer som en kollektiv erfaring“. Det indebærer en risiko for at blive anklaget for manglende autenticitet. 
I den gængse folkelige opfattelse er autenticiteten og uskylden i familie med hinanden, og har man spist af kundskabens træ - ved man frem for bare at væere - ja så er det sket. Men for det første er det en fejlagtig forestilling at ægthed ikke kan høre sammen med valg, refleksivitet og erkendelse. For det andet er den ekspliciterede kultur der inddrages i rettighedskampen ikke ensbetydende med at der ikke stadig er områder af det sociale liv som er uden for eksplicitering, og at man kan opleve sådanne områder som mere eller mindre autentiske. Tove Søvndahl Petersen gør i den forbindelse opmærksom på det paradoks at man i et forsvar for sin egen kultur og for at kunne beholde politisk og $ø$ konomisk selvbestemmelse må kunne tænke, føle, tale og handle som repræsentanterne for de institutioner man er oppe imod, hvad enten det er de udenlandske storbanker eller EU's fiskeridirektorat. Hun udmaler et ganske konkret billede af en kolonial samfundsstruktur og taler i den forbindelse om at den bevidsthed, som et oprindeligt folk i den moderne internationale betydning af ordet, der er blevet født i Grønland, i virkeligheden er blevet født efter at forhandlingerne om hjemmestyre med koloniadministrationen var begyndt. Også Katja Kvaale diskuterer forholdet mellem ,erfaret og repræsenteret kultur", og hun taler om et dialektisk forhold mellem erfaret og repræsenteret kulturel kontinuitet hvor den egentlige „rækkefølge“ bliver uklar.

Hvordan man end forstår forholdet mellem de umiddelbart oplevede kulturudtryk på den ene side, og den bevidst fremstillede og refleksivt udtrykte - og flere af de i dette nummer fremførte eksempler kunne tyde på at der er noget kunstigt i overhovedet at skelne - så er det værd at huske på at kultur og identitet opleves ,essentialistisk“, ligegyldigt i hvor høj grad der kan påvises processer og dynamikker i en historisk udvikling. Samtidig kan der være grund til at minde om at selv om det kan være svært at sige hvad det er, fornemmer og sanser man som oftest om noget er autentisk. Om det har bund i et fælles socialt liv eller om det er fundet på til lejligheden. Det gælder indfødtes såvel som andre folks kultur, og når spørgsmålet om autenticitet så tit trækkes frem i forbindelse med netop indfødte eller oprindelige folk, har det nok så meget at gøre med nogle stereotype opfattelser heraf, som med noget væsentligt forskellige mellem det autentiske hos indfødte og ikke-indfødte. Al kultur er dynamisk, al identitet er i et analytisk perspektiv noget man $\mathrm{g} ø \mathrm{r}$ snarere end noget man har, og autenticitetens karakter er som sådan den samme, omend dens sociale og historiske betingelser kan være forskellige. En rituel performance har andre betingelser hos et regnskovsfolk når de er ladt $\mathrm{i}$ fred, end når de lever i konstant overlevelsestrussel, eller hvis de ender som turistkoryfæer i et økoreservat. Autenticitet er som så meget andet kontekstbestemt. Og alligevel er det til at se forskel, inden for såvel som uden for indfødtes verden. I et område, jeg selv har arbejdet med, som ikke har meget at gøre med indfødtes verden, men som er den afrikanske religiøse kultur i Brasilien hvor deterritorialisering og diaspora er kulturens vilkår, hvor alting har måttet opfindes forfra i en ny national, social og territorial kontekst, og hvor kreativiteten i de daglige overlevelsesstrategier indebærer en usædvanlig stor kulturel opfindsomhed, er det alligevel til at se og mærke forskel på hvad jeg godt tør kalde et autentisk ritual og så den rene maskerade. Inden for området indfødte folk vil det også være muligt at observere en manglende autenticitet. Men den ligger ikke nødvendigvis dér hvor kulturen ekspliciteres bevidst eller refleksivt, fremtvunget af ydre omstændigheder eller som et led $\mathrm{i}$ en overlevelsesstrategi. 


\section{For hvis skyld?}

Antropologien har for så vidt ikke på noget tidspunkt haft studiet af kategorien indfødte folk som objekt. „Barnet“ har skiftet navn gennem historien, som Niels Fock siger, men mens stammer og folkeslag har været objekter, så er indfødte folk som allerede nævnt snarere en politisk end en analytisk kategori. Antropologien kan i dag ikke have denne kategori som objekt som sådan. Men den kan studere de politiske processer hvorigennem de der kalder sig indfødte folk kæmper for selvbestemmelse og den måde hvorpå de bruger henvisning til kultur. Man kan studere yanomamier, buskmænd, hawaianerne, kayapóer, inuitter osv. med deres relationer til den nationalstat de er en del af, og man kan i et globalt perspektiv studere opkomsten af kategorien indfødte folk som en politisk bevægelse, samt de magtcentre og magtkanaler hvorigennem kampen føres og den modstand den møder.

En diskussion der ligger implicit i artiklerne i dette nummer, er forståeligt nok også spørgsmålet om de vestlige menneskerettigheders status i ikke-vestlige samfund, og hele spørgsmålet om hvorvidt den nu så udstrakte brug af menneskerettighedsbegrebet (blot) er en ny form for ideologisk imperialisme - missionsvirksomhed i nye iklædninger. På trods af at denne diskussion ikke tages op direkte, synes den underliggende holdning i artiklerne at være den at, vel vidende menneskerettighederne er en vestlig kulturel konstruktion, dybt indlejret i en bestemt socio- $ø$ konomisk sammenhæng og udsprunget af en ganske bestemt historisk situation, så er de på dette givne punkt i verdenshistorien det mindst ringe instrument indfødte og andre undertrykte grupper har til rådighed i hævdelsen af deres rettigheder via de eksisterende internationale institutioner.

I 1968 da verden for første gang for alvor fik øje for overgrebene på indfødte folk $\mathrm{i}$ Sydamerika - det var især den brasilianske indianerbeskyttelsestjeneste der blev afsløret som den der havde stået bag massakrer på indianere i Amazonas - reagerede det internationale antropologiske samfund prompte. Man dannede IWGIA, som fik hjemsted i Danmark, og franske antropologer sendte et brev til den brasilianske præsident hvori de skrev at antropologer har et særligt bånd til disse små indfødte grupper - natives - der, som det blev hævdet, ved at holde fast i eksistensformer der har været menneskehedens i tusinder af år, har givet os en moralsk lektion: „Ud over deres offer, giver de os den enestående chance for at kende vor egen sande natur som den var før den teknologiske civilizations hvirvelvind der bærer os af sted, har forandret os for altid." (1968). Man talte ligefrem om at disse grupper bar et helligt budskab, og at så længe de ikke af egen fri vilje havde bestemt sig til at skifte livsform, var det vor pligt at respektere den de havde. „Hvis vi ikke respekterer mennesket, med trosformer og skikke, der kan forekomme chokerende og fremmede for os, er det menneskeheden selv vi nedværdiger og udsætter for de alvorligste farer" (ibid.). En højstemt argumentation der godt kan skurre lidt i vore dages ører. Den smager af indfødte folks samfund som en slags menneskehedens laboratorium, og engagementet kan ligne en appel om at bevare disse grupper for menneskehedens skyld snarere end for deres egen.

I dag må man, hvis man skal se på mulighederne for indfødte folks egen frigørelseskamp, spørge til styrken af det internationale samfund. Her gælder det ikke blot FN, det er snarere den globale offentlighed. Det skal blive interessant at se hvor meget den globale offentlighed betyder, om den overhovedet orker at mene noget om indfødte folks ret til selvbestemmelse, og med hvilke argumenter. Om det f.eks. bliver argumenterne om den 
kulturelle diversitet og bevarelse af den menneskelige mangfoldighed - en slags humanitetens kulturparker - eller det virkelig bliver retten til selvbestemmelse i videste forstand - menneskerettighederne forstået som frihed fra undertrykkelse - og herunder også retten til at fralægge sig anderledesheden, og i hvert fald ikke bevare den for andres skyld.

Den kulturelle diversitet kan ikke være hovedargumentet. Hvor meget man end kan holde af den, som antropolog og almindelige verdensborger, er den ikke, og bør den ikke være grundargumentet når man vil hævde selvbestemmelsesretten. For en organisation som IWGIA er det således ikke kulturbevarelsen der er det ideologiske grundlag for arbejdet med indfødte folk, men derimod afskaffelsen af åbenlys uret og kampen for retten til selv at vælge - herunder også fravælge det traditionelle og indgå i moderniteten. Som Katja Kvaale siger, handler det om at udstrække menneskerettighederne, modernitetens anstændighedsgrundlag, til at omfatte alle, også indfødte, mennesker.

Antropologiske resultater kan bruges begge veje, såvel i den politiske konservatismes tjeneste som for indfødte folks frigørelseskamp. Ulla Hasagers eksempler viser at det moderne kulturbegreb kan bruges til lidt af hvert. Om det bliver brugt til skade eller til gavn for den rettighedskamp der føres af indfødte folk, afhænger af brugerne og den politiske og magtmæssige kontekst de indgår i. Det er ikke begrebet - det dynamiske med understregning af fornyelse og dynamik i hvad der opfattes som tradition og kultur - i sig selv der er synderen, ligesom det heller ikke tjener noget formål at trække det gammeldags statiske kulturbegreb frem af stalden i en nok så god sags tjeneste. Antropologien må udvide sit erkendelsesområde, i princippet uafhængigt af hvad der tjener interesserne hos diverse grupper i verden bedst nu og her, men naturligvis ud fra en erkendelse af at enhver form for viden er positioneret, udgår fra et bestemt sted, og at den brug der gøres af den, er bestemt af en etik, politiske forhold og magtkonstellationerne i verden. Der findes ingen håndbog $\mathrm{i}$ antropologisk etik, ligesom der ikke er nogen steder at slå op hvis man vil vide hvordan man laver engageret politisk, anvendt arbejde i frigørelsens eller menneskerettighedernes tjeneste. Det gælder antropologer såvel som indfødte. Også indfødte folks repræsentanter taler ud fra en bestemt position. De kan tilhøre eliten, eller de kan høre til den gruppe der kun mærker deres indfødthed i form af undertrykkelsen, volden og diskriminationen, men slet ikke opfatter sig selv som indfødte i den forstand begrebet bruges i den internationale arena.

Set $i$ et anvendelsesperspektiv er antropologens opgave i dag i lige så høj grad at bruge sin viden og sine metoder til oplysning om de systemer indfødte folk er oppe imod staterne, de globale bevægelser - som det er at formidle hvad der er indfødte folks kultur. Dette kan de i større og større omfang selv, i det omfang de får mulighederne for det. Det giver dog ikke anledning til at lægge pennen, endsige nedlægge hvervet $\mathrm{i}$ frustration over farerne for misbrug af viden, over magttab og autoritetstab, og hård konkurrence fra de menneskers side på hvis vegne nogle fejlagtigt havde troet at kunne udtale sig. Man kan arbejde ud fra forskellige placeringer i det aktuelle akademiske og politiske landskab, og man kan ikke tillade sig at være uopmærksom på betydningen af den position man udtaler sig fra, eller de farer der lurer på misbrug. Men man kan sikre sig. Også dét viser artiklerne i dette nummer af Tidsskriftet Antropologi. 


\section{Note}

1. Se Stofskifte, Tidsskrift for Antropologinr. 9. 1983, Vildhedens Historie; Jens Dahl: Indfødte Folk, København, IWGIA 1992; samt IWGIA's publikationer.

\section{Litteratur}

1968

Open Letter to His Excellency General Arthur Costa E Silva, President of the Republic of Brazil. Current Anthropology 9(5). 